\title{
Prefeeding and the apparent frustration effect ${ }^{1}$
}

\author{
ERNEST D. KEMBLE ${ }^{2}$ AND KEITH N. CLAYTON \\ VANDERBILT UNIVERSITY
}

In a series of three experiments, running speed in a single runway was found to increase following the omission of prefeeding when this was preceded by consistent prefeeding (Apparent Frustration Effect). A similar increase was also found in Ss which had not been previously prefed. It is suggested that the increased running speed of the previously, nonprefed Ss resulted from either rapid generalization of reward expectation from the goalbox or simply from a change in stimulus conditions.

In investigations of the apparent frustration effect (AFE), Ss are trained to traverse the first of two runways, given a small amount of reward in the first goalbox, and then allowed to traverse the second runway for reward in a second goalbox. Second runway running speed is found to increase when reward is omitted from the first goalbox. According to Amsel (1958), the increased vigor of responding results from an emotional response of frustration to nonreward, which increases drive level.

The purpose of the present studies was to determine whether AFE depends on the use of the first runway. Since, according to Amsel (1958), the emotional reaction to nonreward is dependent on the conditioned fractional anticipatory goal response, similar results should be found if Ss were simply placed in the first goalbox. This simply amounts to prefeeding Ss in the startbox of a single runway and then omitting it on $50 \%$ of the trials after running speeds have stabilized.

Since frustration and anticipatory frustration have been used to account for the phenomenon of nonresponse extinction (Dyal, 1962), it seemed reasonable to expect frustration to occur in a previously baited startbox. Experiment 1

Design. This experiment consisted of an initial (preshift) phase until running speed was stabilized and a postshift phase. The principal (AFE) group received prefeeding on every trial during the preshift phase (Group P). During the postshift phase prefeeding was omitted on a random 50\% of the trials. Group P thus yielded two postshift conditions (PP and PN).

Wagner (1959) has suggested a control group which receives reward only in the terminal goalbox to control for any depression of running speed brought about by the reward in the first goalbox. Therefore a second group received no reward in the startbox during both preshift and postshift phases of the experiment (Group NN). Another group was never prefed during the preshift phase but was prefed on every postshift trial (Group NP).

Method. The Ss were 39 adult male albino rats. They were run in a Hunter straight runway ( $4 \times 30$ in.) affixed with a $4 \times 6$ in. startbox (SB) and goalbox (GB).
The GB had clear plastic walls, a floor of aluminum rods, and a brown plastic food cup. The SB had a black ribbed rubber floor, walls covered with black paper, and a white plastic food cup. Running speeds were measured by Cramer standard timers $(.01 \mathrm{sec})$.

The Ss received four trials daily with an intertrial interval of at least $20 \mathrm{~min}$. On each trial $S$ was placed in SB with two $45 \mathrm{mg}$ food tablets present for prefed Ss or none for the nonprefed Ss. After $5 \mathrm{sec}$ the SB door was opened and Ss ran to GB, which contained four $45 \mathrm{mg}$ tablets. When stable running speeds had been attained ( 80 trials), Group $\mathrm{N}$ Ss were assigned to matched groups of 10 Ss each (Groups NN and NP). All Ss received 40 postshift trials.

Results and Discussion. Analysis of preshift speeds revealed, contrary to expectation, that nonprefed Ss ran consistently faster than prefed $S s \quad(F=2.16$, df $=19 / 684, \mathrm{p}<.01$ ).

Examination of postshift running speeds under conditions PN and PP revealed an immediate increase on nonprefed trials while prefed speeds remained consistently lower. These differences were found to be significant by a within Ss analysis of variance $(F=10.75$, df $=1 / 702, p<.005)$. Although this seems to indicate $\mathrm{AFE}$, the fact that the preshift performance of Group $P$ was lower than that of the nonprefed group suggested that the AFE resulted from the removal of the depressing effects of prefeeding. To test this possibility, the postshift performances of condition PN and Group NN (Wagner control) were compared. If nonprefeeding produced any effects over and above the removal of prefeeding depression, the running speed of condition PN should exceed that of Group NN. Examination revealed that the running speed of condition PN increased to approximately the same level as that of Group NN but showed no consistent superiority $(t=0.4)$. Thus, removal of the response depression seems to account for what appeared to be AFE in the postshift phase.

\section{Experiment 2}

It was suspected that the short duration SB confinement and/or the amount prefed was responsible for the response depression in Experiment 1. Experiment 2 was therefore designed as an attempt to eliminate the depression effect found in Experiment 1 and, additionally, to assess the effects of postshift stimulus change. Previous AFE control groups have received consistent postshift treatments (e.g., Groups NN and NP of Experiment 1), while the AFE groups were always shifted from consistent (100\% prefed) to inconsistent (50\% prefed) conditions. Therefore, a control group was added which was nonprefed during the pre- 
shift phase and then received $50 \%$ prefeeding during the postshift phase. Such a control would, in the initial postshift trials at least, assess the effects of change in prefeeding schedule.

Method. The Ss were 24 adult male albino rats. Apparatus and procedures were identical to those in Experiment 1 except for the following changes designed to remove response depression. Reward was reduced to one $45 \mathrm{mg}$ tablet in SB and two in GB. Confinement in SB was increased from 5 to $15 \mathrm{sec}$, and Ss were given two rather than four trials per day.

Eight Ss were randomly assigned to a prefed preshift group while 16 were nonprefed. When running speeds had stabilized (60 trials) the nonprefed Ss were divided into two matched groups. On the following (first postshift) day, prefed Ss began to receive 50\% prefeeding (AFE group). One group of nonprefed Ss continued nonprefed (Wagner control), and the second group, like the AFE group, began to receive $50 \%$ prefeeding (stimulus change control group).

Results and Discussion. Examination of preshift running speeds revealed that the changes in procedure not only did away with response depression but produced consistently faster running speeds in the prefed group. This difference was significant by analysis of variance $(F=4.36, \mathrm{df}=1 / 23, \mathrm{p}<.05)$.

Turning to the postshift data, the AFE group once again ran faster on nonprefed trials, but comparison of $\mathrm{AFE}$ and stimulus change control group revealed that this was true of both groups $(F=5.20, d f=1 / 182$, $p<.05)$. This effect did not interact with postshift days or preshift treatment. It thus appeared that an AFE had been produced in Ss which had never been prefed and therefore could not have built up an "expectation of reward." This finding is somewhat obsured, however, by the differences in preshift performance. A further experiment in which prefed and nonprefed groups did not differ in their preshift performance was felt to be necessary to confirm this finding.

\section{Experiment 3}

This experiment was designed (a) to replicate Experiment 2 using a larger number of Ss and (b) to either eliminate response facilitation and/or depression or assess their contribution by the use of both prefed and nonprefed control groups.

Method. The Ss were 52 adult male albino rats. The apparatus and procedures were identical to those in Experiment 2 except that prefed Ss received two $45 \mathrm{mg}$ tablets in SB and four in GB. A control group which was prefed on all trials during both pre- and postshift phases was added.

Twenty-six Ss were randomly assigned to a prefed group and the remaining 26 assigned to a nonprefed group. When running speeds stabilized (56 trials) Ss in each group were ranked according to mean running speed and divided into two matched groups. Thirteen prefed Ss constituted the AFE group while 13 continued on a prefed schedule for every trial (prefed control). Thirteen nonprefed Ss began to receive prefeeding on $50 \%$ of the trials (stimulus change control group), and 13 Ss continued nonprefed on every trial (Wagner control). All Ss received 40 postshift trials.

Results. Analysis of preshift performance revealed no significant difference between the prefed and nonprefed groups, with running speeds for both groups similar on all preshift trials.

Comparison of the postshift performance of the AFE and stimulus change control groups revealed that, as before, Ss in both groups ran consistently faster on nonprefed trials as compared to prefed trials ( $F=4.38$, df $=3 / 71, p<.01$ ). Furthermore, this effect did not interact with preshift treatment or postshift days. Postshift performance of both prefed and nonprefed controls was quite similar and showed no significant differences when compared by analysis of variance. Comparison of control groups with the AFE and stimulus change control groups failed to show any significant differences.

The increase in running speed found in the stimulus change control group may be explained in two possible ways: (1) either the change in prefeeding schedule alone was sufficient to produce an increase on nonprefed trials (a stimulus change enhancement), or (2) the expectation of reward in GB generalized to SB rapidly when prefeeding was introduced. To test these possibilities the performance of both groups was compared on the first 10 postshift trials. Although there seemed to be a tendency for AFE to develop more rapidly in the $A F E$ group than the stimulus change control group, analysis of variance failed to indicate any significant differences for either group. Thus, whether the increase in running speed was due to the frustrative effects of nonprefeeding or simply due to stimulus change cannot be determined from the present data.

\section{References}

AMSEL, A. The role of frustrative nonreward in noncontinuous reward situations. Psychol. Bull., 1958, 55, 102-119.

AMSEL, A., \& ROUSSEL, J. Motivational properties of frustration: I. effect on a running response of the addition of frustration to the motivational complex. J. exp. Psychol., 1952, 43, 363-368.

DYAL, J. A. Latent extinction as a function of number and duration of pre-extinction exposures. J. exp. Psychol., 1962, 63, 98-104. WAGNER, A. R. The role of reinforcement and nonreinforcement in an "Apparent Frustration Effect". J. exp. Psychol., 1959, 57, 130-136.

Notes

1. This research was partially supported by Grant HD-00924 held by Keith N. Clayton from the National Institute of Health, United States Public Health Service.

2. Now at the University of Minnesota, Morris. 